\title{
Sintesis Senyawa Turunan Amoksilin Dan Uji Aktivitas Antibakterinya Terhadap Bakteri Salmonella typhi
}

\author{
Hadi Barru Hakam Fajar Siddiq, Dewi Rashati, dan Dewi Riskha Nurmalasari \\ Akademi Farmasi Jember \\ Korespondensi: Hadi Barru Hakam Fajar Siddiq \\ Email: hakamfajar@gmail.com
}

Submitted: 05-10-2018, Revised: 30-10-2018, Accepted : 06-12-2018

\begin{abstract}
ABSTRAK: Sintesis senyawa turunan amoksisilin telah dilakukan melalui reaksi amoksisilin dengan 4-tbutilbenzoil klorida. Produk yang dihasilkan telah dikarakterisasi dengan uji organoleptis, penentuan titik leleh, KLT, spektrofotometri UV-Vis, dan spektrofotometri FTIR. Pengujian aktivitas antibakteri turunan senyawa amoksisilin terhadap bakteri Salmonella typhi dilakukan dengan menggunakan metode difusi. Hasil penelitian menunjukkan bahwa produk hasil sintesis berbentuk serbuk berwarna kuning muda; sedikit pahit; titik leleh $13^{\circ} \mathrm{C}$; nilai $\mathrm{Rf} 0,86$; $\mathrm{pH} 7,7$; dan memiliki panjang gelombang maksimum (UV) sebesar $286 \mathrm{~nm}$. Spektrum FTIR turunan amoksisilin menunjukkan puncak pada bilangan gelombang 3271 cm-1 (-NH amin), 2962 cm-1 (-CH aromatic), 1633 cm-1 (-C=0 keton), dan lainnya. Hasil uji antibakteri menunjukkan bahwa senyawa turunan amoksisilin tidak membentuk zona hambat. Dengan demikian, senyawa turunan amoksisilin tidak dapat digunakan untuk menghambat bakteri Salmonella typhi.
\end{abstract}

Kata Kunci: sintesis; turunan amoksisilin; Salmonella typhi

\begin{abstract}
The synthesis of amoxicillin derivate was carried out by reacting amoxicillin with 4-t-butylbenzoil chloride. The product was characterized by organoleptic test, melting point determination, TLC, UV/Vis Spectrophotometry, and FTIR Spectrophotometry. Antibacterial activity of amoxicillin derivate against Salmonella typhi was tested using diffusion method. Result showed that the product has characteristic as follow: light yellow powder, bitter bite, melting point of $132{ }^{\circ} \mathrm{C}$, Rf value of $0.86, \mathrm{pH}$ value of 7.7 , maximum wavelength (uv) of 286 $\mathrm{nm}$. Moreover, FTIR spectra of amoxicillin derivate exhibited peaks at $3271 \mathrm{~cm}-1$ (-NH amine), $2962 \mathrm{~cm}-1$ (-CH aromatic), $1633 \mathrm{~cm}-1$ (-C=O ketone), and other. Antibacterial test showed that amoxicillin derivate was unable to form a clear zone around the disc paper. Amoxicillin derivate cannot be used for the treatment of Salmonella typhi.
\end{abstract}

Keywords: synthesis; amoxicillin derivate; Salmonella typhi 


\section{Pendahuluan}

Bakteri enterik patogen adalah bakteri yang umum menginfeksi saluran pencernaan baik hewan maupun manusia. Bakteri tersebut banyak berasal dari makanan dan air yang telah terkontaminasi. Bakteri tersebut merupakan kelompok batang gram negatif dan gram positif yang banyak dibiakkan di laboratorium klinis dan paling umum menyebabkan penyakit saluran cerna. Famili yang termasuk bakteri enterik patogen yang sering mengkontaminasi makanan mencakup beberapa genus, diantaranya Escherichia coli, Salmonella typhi, Pseudomonas aeruginosa, Staphylococcus aureus, dan Bacillus substilis.

Penyakit infeksi merupakan ancaman bagi kelangsungan hidup manusia dan telah menjadi penyebab kematian ketiga di dunia [1]. Penanggulangan penyakit infeksi umumnya dilakukan dengan pemberian antibiotik. Penggunaan antibiotik yang tidak tepat seperti kurang tepatnya indikasi penggunaan, penggunaan bebas oleh masyarakat, serta dosis dan lama pemberian yang tidak tepat akan menimbulkan masalah baru yaitu meningkatnya resistensi bakteri terhadap antibiotik [2,3]. Kejadian resistensi bakteri terus meningkat di berbagai belahan dunia. Namun peningkatan itu diiringi oleh kecenderungan yang menurun dari pengembangan antibiotik baru $[4,5]$. Untuk mengatasi masalah tersebut, diperlukan upaya pengembangan antibiotik baru $[6,7]$.

Amoksisilin adalah turunan penisilin yang strukturnya mirip dengan ampisilin, dengan perbedaan adanya gugus hidroksi pada posisi para cincin benzena. Beberapa keuntungan amoksisilin dibanding ampisilin adalah absorbsi obat dalam saluran cerna lebih sempurna sehingga kadar dalam plasma lebih tinggi. Kadar darah maksimalnya dicapai dalam 1 jam setelah pemberian oral [8]. Amoksisilin tidak efektif terhadap beberapa bakteri antara lain Pseudomonas aeruginosa [9] dan Staphylococcus aureus [10]. Oleh karena itu, diperlukan modifikasi senyawa amoksisilin yang dapat meningkatkan kinerja atau mengurangi resistensi terhadap bakteri.

Di lain pihak, 4-t-butilbenzoil klorida telah digunakan dalam sintesis senyawa obat, seperti N-(4-t-butilbenzoil)-p-aminofenol [11,12]. Senyawa 4-t-butilbenzoil klorida mampu memberikan dampak yaitu dengan bertambahnya lipofilisitas senyawa, maka aktivitas antiinflamasi senyawa N-(4-t-butilbenzoil)-p-aminofenol semakin kuat [11].

Pada penelitian ini telah dilakukan sintesis senyawa amoksisilin dengan 4-t-butilbenzoil klorida yang menghasilkan senyawa turunan amoksisilin melalui reaksi substitusi nukleofilik gugus amina primer amoksisilin dengan atom karbon dari gugus karbonil 4-t-butilbenzoil klorida. Sintesis ini bertujuan untuk membuat turunan amoksisilin sebagai antibakteri terhadap Salmonella typhi. Selanjutnya dilakukan karakterisasi sifat fisik dan kimia antara lain, organoleptis, titik leleh, nilai Rf, pH, scanning panjang gelombang maksimum, dan ikatan gugus dalam senyawa turunan amoksisilin, serta uji aktivitas antibakteri terhadap bakteri Salmonella typhi.

\section{Bahan dan metode}

\subsection{Alat dan bahan}

Peralatan yang digunakan dalam penelitian ini antara lain pH meter (Ohaus Starter 3100 pH Bench), rotary evaporator (RV 8), melting point tester (Omega), spektrofotometer UV-Vis (Thermo Scientific Genesys 10S UV-Vis), spektrofotometer IR (Shimadzu IR Affinity-1S), petridish, jangka sorong, autoklaf (Westlab), inkubator, mikropipet, ose, bunsen, Laminar Air Flow (Stainless steel Indiamart), colony counter, dan alat-alat gelas laboratorium. Bahan-bahan yang digunakan dalam penelitian ini adalah amoksisilin trihidrat (pharmaceutical grade), 4-t-butilbenzoilklorida (Merck), tetrahidofuran (Merck), kalium hidroksida (Merck), etil asetat (Merck), etanol p.a. 
(Merck), metanol p.a. (Merck), aseton (Merck), plat KLT silica gel 60 F 254, aquabides, Nutrient Agar dan Nutrient Broth, serta kertas cakram.

\subsection{Sintesis senyawa turunan amoksisilin}

Sebanyak 28,8 mmol amoksisilin ditambahkan dengan $100 \mathrm{~mL}$ tetrahidrofuran dan $20 \mathrm{~mL}$ aquabides. Campuran diaduk pada suhu $0-5^{\circ} \mathrm{C}$, kemudian ditambahkan larutan kalium hidroksida $2 \mathrm{~N}$. Selanjutnya $\mathrm{pH}$ diatur antara 6,8 sampai 7,2. Kemudian ditambahkan 25 mmol 4-t-butilbenzoilklorida dalam $40 \mathrm{ml}$ tetrahidrofuran tetes demi tetes. Campuran dibiarkan selama beberapa jam pada suhu kamar sambil diaduk. Selanjutnya tetrahidrofuran dalam campuran diuapkan dan padatan yang diperoleh dilarutkan dalam $300 \mathrm{~mL}$ aquabides. Tahap selanjutnya, larutan diekstraksi dengan $250 \mathrm{~mL}$ etil asetat. Fase air dipisahkan. Fase etil asetat ditambahkan $250 \mathrm{~mL}$ etil asetat dan didinginkan. Etil asetat dalam larutan diuapkan. Untuk menghilangkan sisa etil asetat, zat padat yang diperoleh dilarutkan dalam metanol kemudian diuapkan kembali hingga kering [13].

\subsection{Karakterisasi organoleptis senyawa turunan amoksisilin}

Senyawa turunan amoksisilin hasil sintesis dan senyawa amoksisilin masing-masing diamati bentuk, warna, dan rasa menggunakan tiga responden.

\subsection{Karakterisasi titik leleh senyawa turunan amoksisilin}

Senyawa turunan amoksisilin hasil sintesis dan senyawa amoksisilin masing-masing dimasukkan ke dalam pipa kapiler sampai setinggi 2,5-3 mm. Selanjutnya, pipa kapiler berisi sampel dimasukkan ke dalam melting point tester dan diamati titik leleh sampel.

\subsection{Karakterisasi nilai pH senyawa turunan amoksisilin}

1 g senyawa turunan amoksisilin dilarutkan dalam $100 \mathrm{ml}$ etanol 70\%, kemudian diukur $\mathrm{pH}$ nya dengan menggunakan $\mathrm{pH}$ meter.

\subsection{Karakterisasi nilai Rf senyawa turunan amoksisilin}

$1 \mathrm{mg}$ sampel dilarutkan ke dalam $100 \mathrm{ml}$ etanol 70\%, lalu diuapkan hingga kental, kemudian ditotolkan pada plat KLT silica gel 60 F 254 menggunakan pipa kapiler. Selanjutnya, plat KLT dieluasi dengan fase gerak metanol:aseton:etil asetat (3:1:1).

\subsection{Karakterisasi panjang gelombang maksimum senyawa turunan amoksisilin}

$1 \mathrm{mg}$ sampel dilarutkan ke dalam $100 \mathrm{ml}$ etanol 70\%. Selanjutnya, sampel dimasukkan ke dalam spektrofotometer UV-Vis dan dilakukan scanning panjang gelombang pada daerah 200$400 \mathrm{~nm}$.

\subsection{Karakterisasi gugus fungsi senyawa turunan amoksisilin}

Sejumlah senyawa turunan amoksisilin hasil sintesis atau amoksisilin dicampur homogen dengan kalium bromida dan dibuat bentuk pellet dengan penekan hidrolik, lalu spektrumnya diamati pada bilangan gelombang $4000-400 \mathrm{~cm}^{-1}$.

\subsection{Uji aktivitas antibakteri senyawa turunan amoksisilin}

Metode pengujian aktivitas antibakteri yang digunakan yaitu metode difusi menggunakan kertas cakram berdiameter $6 \mathrm{~mm}$. Pada masingmasing senyawa dengan konsentrasi yang berbeda diambil sebanyak $20 \mu \mathrm{L}$ dan diteteskan pada kertas cakram lalu ditunggu sampai jenuh [14]. Suspensi bakteri diambil sebanyak $100 \mu \mathrm{L}$, dimasukkan dalam media Nutrient Agar (NA) lalu dituang ke dalam petridish steril dan ditunggu hingga memadat. Kertas cakram yang telah dijenuhkan dengan berbagai konsentrasi diletakkan di atas permukaan media agar. Kontrol positif yang digunakan adalah amoksisilin, sedangkan kontrol negatifnya adalah etanol 70\%. Lalu diinkubasi selama 24 jam pada suhu $37^{\circ} \mathrm{C}$. Pengujian aktivitas antibakteri dilakukan sebanyak tiga kali pengulangan [15].

Aktivitas antibakteri dikatakan positif apabila 
terbentuk zona hambat berupa zona bening di sekitar kertas cakram. Pengukuran diameter zona hambat dilakukan dengan mengurangi diameter hambatan dengan diameter kertas cakram (6 $\mathrm{mm}$ ) [16]. Klasifikasi respon hambatan pertumbuhan bakteri yaitu apabila terbentuk diameter 0-3 mm respon hambatannya lemah, 3-6 mm respon hambatannya sedang, dan lebih dari $6 \mathrm{~mm}$ respon hambatannya kuat [17].

\subsection{Penentuan konsentrasi hambat minimal (KHM) dan konsentrasi bakterisida minimal (KBM)}

Pengujian dilakukan dengan metode dilusi. Pada perlakuan, diambil konsentrasi senyawa turunan amoksisilin antara konsentrasi terendah yang tidak dapat menghambat pertumbuhan bakteri patogen sampai konsentrasi terendah yang dapat menghambat pertumbuhan bakteri. Aquadest digunakan sebagai kontrol negatif, sedangkan amoksisilin dan kloramfenikol pada konsentrasi 100 ppm sebagai kontrol positif.

Sebanyak $1 \mathrm{~mL}$ setiap bahan (perlakuan, kontrol negatif, dan kontrol positif) dilarutkan ke dalam $9 \mathrm{~mL}$ garam fisiologis 0,85\%. Diambil 100 $\mu \mathrm{L}$ larutan tersebut lalu di-spread plate pada media Nutrient Agar (NA) yang sudah berisi $100 \mu \mathrm{L}$ bakteri patogen, lalu diinkubasi selama 24-48 jam. Jumlah koloni dari masing-masing perlakuan tersebut kemudian dihitung. Nilai KHM diperoleh dari perlakuan yang memiliki jumlah koloni paling sedikit, sedangkan nilai KBM diperoleh dari perlakuan yang tidak mengalami pertumbuhan koloni bakteri patogen [18].

\section{Hasil dan pembahasan}

\subsection{Hasil penentuan organoleptis senyawa}

Karakterisasi organoleptis pada penelitian ini bertujuan untuk mengamati bentuk, warna, dan rasa pada senyawa turunan amoksisilin hasil sintesis dan senyawa amoksisilin. Karakterisasi dilakukan dengan alat indera atau sensorik [19]. Dalam mengamati bentuk, warna, dan rasa tersebut digunakan 3 responden agar hasil lebih objektif. Data hasil karakterisasi organoleptis senyawa turunan amoksisilin dan amoksisilin ditunjukkan pada tabel 1. Hasil yang diperoleh dari karakterisasi organoleptis menunjukkan bahwa senyawa turunan amoksisilin memiliki bentuk serbuk, berwarna kuning muda dan sedikit pahit. Sedangkan senyawa amoksisilin memiliki bentuk butir, berwarna putih dan sedikit pahit. Hasil dari karakterisasi organoleptis tersebut menunjukkan bahwa senyawa turunan amoksisilin dengan amoksisilin merupakan senyawa yang berbeda.

\subsection{Hasil karakterisasi titik leleh}

Data karakterisasi titik leleh senyawa turunan amoksisilin dan amoksisilin ditunjukkan pada tabel 2. Berdasarkan data tersebut dapat dilihat bahwa senyawa turunan amoksisilin memiliki titik leleh $132^{\circ} \mathrm{C}$ sedangkan amoksisilin memiliki titik leleh $194^{\circ} \mathrm{C}$. Dengan demikian, kedua senyawa memiliki titik leleh yang berbeda. Hasil uji titik leleh amoksisilin pada penelitian ini berbeda dengan penelitian yang dilakukan oleh $\mathrm{Ku}$ sumowati (2011) yaitu $222-224^{\circ} \mathrm{C}$ [20], namun sama dengan yang diteliti oleh Ramos (2012) yaitu $194^{\circ} \mathrm{C}$ [21]. Hasil dari uji titik leleh tersebut menunjukkan bahwa senyawa turunan amoksisilin merupakan senyawa yang berbeda dengan amoksisilin.

\subsection{Hasil penentuan nilai $p H$}

Data uji pH dari senyawa turunan amoksisilin dan amoksisilin ditunjukkan pada tabel 3 . Berdasarkan tabel tersebut dapat dilihat bahwa senyawa turunan amoksisilin memiliki pH 7,7 sedangkan amoksisilin memiliki pH 7,6.

\subsection{Hasil karakterisasi nilai Rf}

Hasil penentuan nilai Rf amoksisilin dan turunannya menggunakan metanol:aseton:asam asetat (3:1:1) sebagai fase gerak dapat dilihat pada tabel 4. Nilai Rf senyawa turunan amoksisilin dan amoksisilin masing-masing adalah 0,86 dan 0,87 . Hasil tersebut berbeda dengan yang 
Tabel 1. Organoleptis amoksisilin dan turunan amoksisilin

\begin{tabular}{llllllllll}
\hline Senyawa & Bentuk & \multicolumn{3}{c}{ Warna } & \multicolumn{3}{c}{ Rasa } \\
\cline { 2 - 9 } & R1 & R2 & R3 & R1 & R2 & R3 & R1 & R2 & R3 \\
\hline $\begin{array}{l}\text { Turunan amok- } \\
\text { sisilin }\end{array}$ & Serbuk & Serbuk & Serbuk & $\begin{array}{l}\text { Kuning } \\
\text { muda }\end{array}$ & $\begin{array}{l}\text { Kuning } \\
\text { muda }\end{array}$ & $\begin{array}{l}\text { Kuning } \\
\text { muda }\end{array}$ & $\begin{array}{l}\text { Sedikit } \\
\text { pahit }\end{array}$ & $\begin{array}{l}\text { Sedikit } \\
\text { pahit }\end{array}$ & $\begin{array}{l}\text { Sedikit } \\
\text { pahit }\end{array}$ \\
Amoksisilin & Butir & Butir & Butir & Putih & Putih & $\begin{array}{l}\text { Putih } \\
\text { Pedikit }\end{array}$ & $\begin{array}{l}\text { Sedikit } \\
\text { pahit }\end{array}$ & $\begin{array}{l}\text { Sedikit } \\
\text { pahit }\end{array}$ \\
\hline
\end{tabular}

Tabel 2. Titik leleh amoksisilin dan turunan amoksisilin

\begin{tabular}{lllll}
\hline Senyawa & \multicolumn{2}{l}{ Titik leleh $\left({ }^{\circ} \mathbf{C}\right)$} & & Rata-rata \\
\cline { 2 - 5 } & $\mathbf{R 1}$ & R2 & R3 & 132 \\
\hline Turunan amoksisilin & 132 & 132 & 132 & 194 \\
\hline Amoksisilin & 194 & 194 & 194 & 194 \\
\hline
\end{tabular}

Tabel 3. Nilai pH amoksisilin dan turunan amoksisilin

\begin{tabular}{lllll}
\hline Senyawa & pH & & & \\
\cline { 2 - 5 } & R1 & R2 & R3 & Rata-rata \\
\hline Turunan amoksisilin & 7,7 & 7,7 & 7,7 & 7,7 \\
Amoksisilin & 7,5 & 7,6 & 7,8 & 7,6 \\
\hline
\end{tabular}

Tabel 4. Nilai Rf amoksisilin dan turunan amoksisilin

\begin{tabular}{lllll}
\hline Senyawa & \multicolumn{2}{l}{ Nilai Rf } & & \\
\cline { 2 - 5 } & R1 & R2 & R3 & Rata-rata \\
\hline Turunan amoksisilin & 0,88 & 0,86 & 0,85 & 0,86 \\
Amoksisilin & 0,86 & 0,89 & 0,85 & 0,87 \\
\hline
\end{tabular}

Keterangan: $\mathrm{R}=$ Replikasi

diteliti oleh Kusumawati (2011) yaitu 0,53 [22].

\subsection{Hasil karakterisasi panjang gelombang maksimum}

Scanning panjang gelombang maksimum senyawa turunan amoksisilin dan amoksisilin dilakukan pada panjang gelombang 200-400 nm (gambar 1).

\subsection{Hasil karakterisasi FTIR}

Uji FTIR dilakukan untuk mengetahui ikatan gugus fungsi yang terbentuk pada senyawa turunan amoksisilin. Hasil tersebut menjadi salah satu acuan bahwa senyawa turunan amoksisilin yang disintesis telah terbentuk. Hasil uji FTIR ditunjukkan pada gambar 2 .
Berdasarkan spektrum FTIR senyawa turunan amoksisilin mempunyai puncak-puncak pada bilangan gelombang $3271 \mathrm{~cm}^{-1}$ (-NH amina), 2962 $\mathrm{cm}^{-1}$ (-CH aromatik), $1633 \mathrm{~cm}^{-1}$ (-C=0 keton), dan puncak-puncak lain. Hasil tersebut berbeda dengan spektrum amoksisilin yang terdapat puncak pada bilangan gelombang $1771 \mathrm{~cm}^{-1}$ yang menunjukkan ikatan gugus $-\mathrm{C}=\mathrm{O}$ amida yang tidak dimiliki oleh senyawa turunan amoksisilin. Namun, masih perlu analisis lebih lanjut untuk mendapatkan struktur senyawa turunan amoksisilin.

\subsection{Hasil uji aktivitas antibakteri}

Tahap selanjutnya adalah pengujian aktivitas antibakteri. Pengujian dilakukan dengan menggunakan metode difusi cakram dan hasilnya di- 


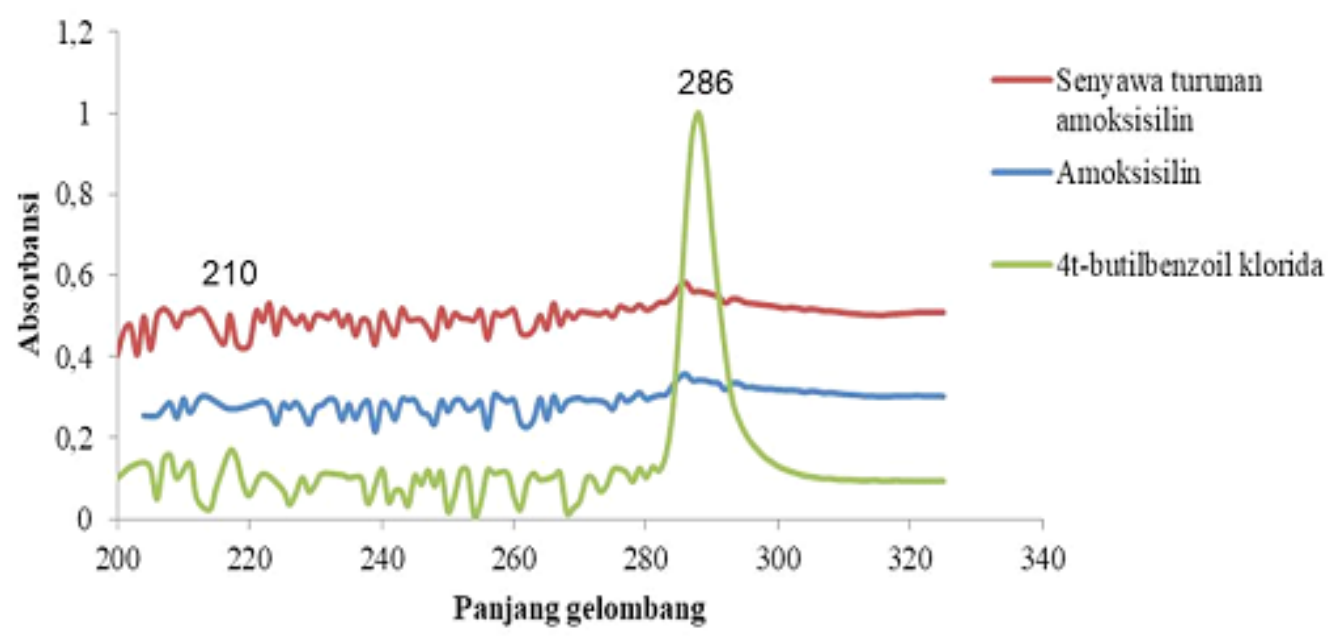

Gambar 1. Hasil scanning panjang gelombang maksimum turunan amoksisilin dan amoksisilin

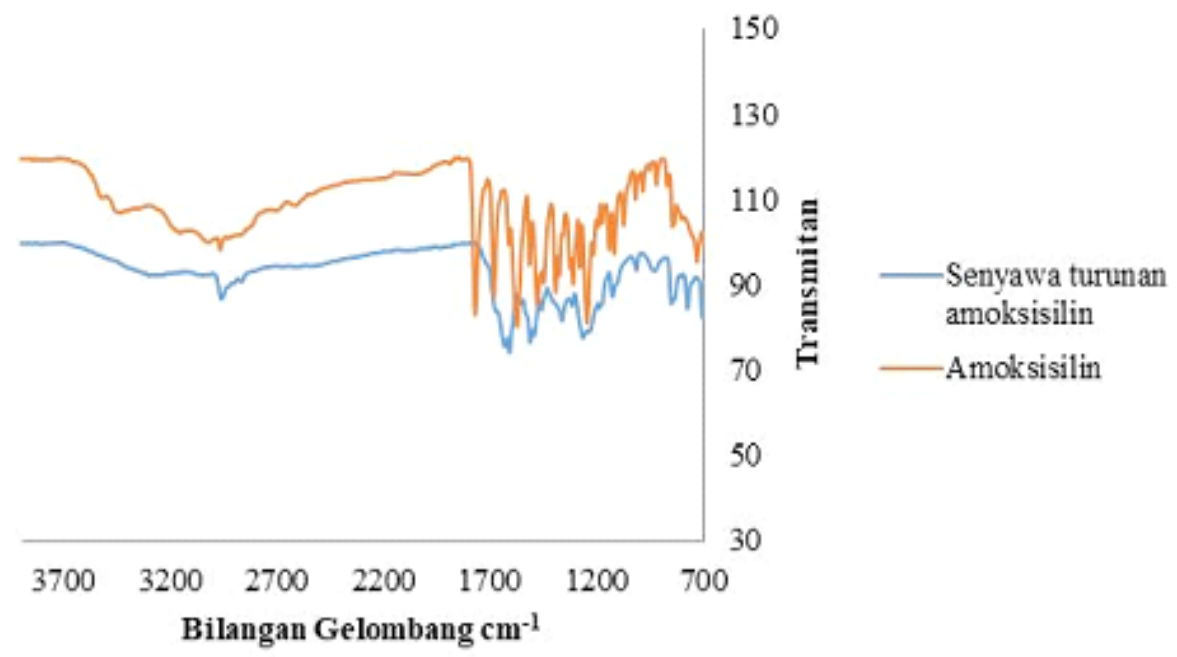

Gambar 2. Spektra FTIR senyawa turunan amoksisilin dan amoksisilin

Tabel 5. Diameter zona hambat pertumbuhan Salmonella typhi

\begin{tabular}{|c|c|c|c|c|c|c|c|c|}
\hline \multirow[t]{2}{*}{ No } & \multirow[t]{2}{*}{ Bahan } & \multirow[t]{2}{*}{ Senyawa } & \multirow[t]{2}{*}{ Ulangan } & \multicolumn{4}{|c|}{ Diameter (mm) } & \multirow{2}{*}{$\begin{array}{l}\text { Respon } \\
\text { hambat }\end{array}$} \\
\hline & & & & $\begin{array}{l}\text { Zona kese- } \\
\text { luruhan }\end{array}$ & $\begin{array}{l}\text { Kertas } \\
\text { cakram }\end{array}$ & $\begin{array}{l}\text { Zona } \\
\text { hambat }\end{array}$ & Rata-rata & \\
\hline \multirow[t]{3}{*}{1} & \multirow[t]{3}{*}{ Perlakuan } & \multirow{3}{*}{$\begin{array}{l}\text { Turunan } \\
\text { amoksisilin } \\
100 \mathrm{ppm}\end{array}$} & I & 0 & \multirow[t]{3}{*}{6} & 0 & \multirow[t]{3}{*}{0} & \multirow{3}{*}{$\begin{array}{l}\text { Tidak } \\
\text { ada }\end{array}$} \\
\hline & & & II & 0 & & 0 & & \\
\hline & & & III & 0 & & 0 & & \\
\hline \multirow[t]{6}{*}{2} & \multirow[t]{6}{*}{$\mathrm{K}(+)$} & \multirow{3}{*}{$\begin{array}{l}\text { Amoksisilin } \\
100 \text { ppm }\end{array}$} & I & 0 & \multirow[t]{3}{*}{6} & 0 & \multirow[t]{3}{*}{0} & \multirow{3}{*}{$\begin{array}{l}\text { Tidak } \\
\text { ada }\end{array}$} \\
\hline & & & II & 0 & & 0 & & \\
\hline & & & III & 0 & & 0 & & \\
\hline & & \multirow{3}{*}{$\begin{array}{l}\text { Kloramfenikol } \\
100 \text { ppm }\end{array}$} & I & 20,5 & \multirow[t]{3}{*}{6} & 14,5 & \multirow[t]{3}{*}{14,7} & \multirow[t]{3}{*}{ Kuat } \\
\hline & & & II & 22 & & 16 & & \\
\hline & & & III & 19,5 & & 13,5 & & \\
\hline \multirow[t]{3}{*}{3} & \multirow[t]{3}{*}{$\mathrm{K}(-)$} & \multirow[t]{3}{*}{ Etanol 70\% } & I & 0 & \multirow[t]{3}{*}{6} & 0 & \multirow[t]{3}{*}{0} & \multirow{3}{*}{$\begin{array}{l}\text { Tidak } \\
\text { ada }\end{array}$} \\
\hline & & & II & 0 & & 0 & & \\
\hline & & & III & 0 & & 0 & & \\
\hline
\end{tabular}

$\mathrm{K}(+)$ : Kontrol positif, $\mathrm{K}(-)$ : Kontrol negatif 
tunjukkan pada Tabel 5.

Berdasarkan Tabel 5 ditunjukkan bahwa senyawa turunan amoksisilin pada konsentrasi 100 ppm dan amoksisilin 100 ppm, serta kontrol negatif etanol 70\% masing-masing tidak dapat membentuk zona hambat. Namun, kontrol positif kloramfenikol 100 ppm mampu menghambat pertumbuhan Salmonella typhi karena membentuk zona hambat. Dengan demikian, senyawa turunan amoksisilin tidak dapat digunakan untuk pengobatan demam thypoid akibat bakteri Salmonella typhi.

\section{Kesimpulan}

Berdasarkan penelitian yang telah dilakukan dapat diperoleh kesimpulan sebagai berikut :

1. Senyawa turunan amoksisilin hasil sintesis memiliki bentuk serbuk, warna kuning muda, sedikit pahit, titik leleh $132^{\circ} \mathrm{C}$, Rf 0,86, pH 7,7, panjang gelombang maksimum $286 \mathrm{~nm}$ dan memiliki puncak-puncak pada bilangan gelombang $3271 \mathrm{~cm}^{-1}$ (-NH amina), $2962 \mathrm{~cm}^{-1}$ (-CH aromatik), $1633 \mathrm{~cm}^{-1}$ (-C=0 keton).

2. Senyawa turunan amoksisilin tidak membentuk zona hambat terhadap Salmonella typhi sehingga pengujian KHM dan KBM tidak dapat dilakukan.

\section{Ucapan terimakasih}

Ucapan terima kasih diucapkan kepada berbagai pihak yang telah membantu dalam penyelesaian penelitian ini, antara lain:

1. Kemenristek Dikti, yang telah memberikan bantuan pendanaan dalam penelitian ini.

2. Akademi Farmasi Jember, yang telah memberikan fasilitas dalam penyelesaian penelitian.

3. Laboran laboratorium Kimia dan Teknologi Farmasi Akademi Farmasi Jember yang telah membantu dalam penyelesaian penelitian ini.

4. Pihak lain yang telah membantu terlaksananya penelitian.

\section{Daftar pustaka}

1. Putin V. Masalah Pendidikan dan Penyakit Infeksi. Info Aktual. www.litbang.depkes.go.id/aktual/ kliping/vladimir. Diakses tanggal 12 Desember 2017.

2. Dzen SM, Roekistiningsih S, Sanarto, Sri W. Bakteriologi medik. Malang: Bayumedia Publishing 2003.

3. Nah YK, Rumawas M, Wijaya WH. Survei Peresapan Antimikroba Oral untuk Anak Balita pada Apotek-Apotek di Wilayah Jakarta Barat. Jurnal Kedokteran Meditek. 2004;12(32).

4. Buntaran L. Infeksi Nosokomial: Menggantung Harapan pada Antibiotik Anyar. Farmacia. 2007;6(11):46-7.

5. Finch R, Hunter PA. Antibiotic resistance-action to promote new technologies: report of an EU Intergovernmental Conference held in Birmingham, UK, 12-13 December 2005. J. Antimicrob. Chemother, 2006;58(Suppl_1):i3-22.

6. Spellberg B, Powers JH, Brass PE, Miller LG, Jr JE. Trends in Antimicrobial Drug Development: Implications for The Future. Clin. Infect. Dis. 2004;38(9):1279-86.

7. Yoneyama H, Katsumata R. Antibiotic resistance in bacteria and its future for novel antibiotic development. Biosc Biotechnol and Biochem. 2006;70(5):1060-75.

8. Soekardjo B, Siswandono. Sintesis Senyawa Baru Turunan N-Benzoilamoksisilin untuk Meningkatkan Aktivitas terhadap Bakteri GramPositif dan Gram-Negatif. Laporan Riset Unggulan terpadu VI Bidang Ilmu Kimia dan Proses; 2000.

9. Siswandono, Soekardjo B. Prinsip-Prinsip Rancangan Obat. Surabaya: Airlangga University Press; 2016.

10. Shituu AO, Okon K, Adesida S, Oyedara O, Witte W, Strommrnenger B, Layer F, Nubel U. Antibiotic Resistance and Molecular Epidemiology of Staphylococcus aureus in Nigeria. BMC Microbiology. 2011;11:92.

11. Susilowati SS, Handayani SN. Sintesis dan Uji 
Aktivitas Analgetika-Antiinflamasi Senyawa N-(4t-butilbenzoil)-p-Aminofenol. Molekul. 2006;1(1):36-40.

12. Siddiq HBHF, Eryani MC, Suryaningsih F. Sintesis Analgetika-Antiinflamasi Senyawa N-(4tButilbenzoil)-P-Aminofenol Menggunakan Katalis Heterogen MgF2. Jurnal Ilmu Dasar. 2018;19(1): 57-62.

13. Soekardjo B. Sintesis dan Hubungan Struktur dengan Aktivitas In vitro dari Suatu Seri Turunan Bensoil N-Ampisilin Baru. Disertasi. Universitas Airlangga. Surabaya; 1989.

14. Ningsih AP, Agustien A. Uji Aktivitas Antibakteri Ekstrak Kental Tanaman Pisang Kepok Kuning (Musa paradisiaca Linn.) terhadap Staphylococcus aureus dan Escherichia coli. J. Bio. UA. 2013;2(3):207-13.

15. Saraswati FN. Uji Aktivitas Antibakteri Ekstrak Etanol 96\% Limbah Kulit Pisang Kepok (Musa balbisiana) terhadap Bakteri Penyebab Jerawat (Staphylococcus epidermis, Staphylococcus aureus, dan Propionibacterium acne). Skripsi. Jakarta: Fakultas Kedokteran dan Ilmu Kesehatan UIN Syarif Hidayatullah; 2015.

16. Hermawan A, Hana W, Wiwiek T. Pengaruh Ekstrak Daun Sirih (Piper betle L.) terhadap Pertumbuhan Bakteri Staphylococcus aureus dan Escherichia coli dengan Metode Difusi Disk. Artikel ilmiah. Fakultas Kedokteran Hewan UNAIR Surabaya; 2007
17. Pan X, Chen F, Wu T, Tang H, Zhao Z. The acid, bile tolerance and antimicrobial property of Lactobacilus acidophilus NIT. Food Control. 2009;20(6):598-602.

18. Pratiwi ST. Mikrobiologi farmasi. Jakarta Erlangga; 2008.

19. Nasiru M. Effect of Cooking Time and Potash Concentration on Organoleptic Properties of Red and White Meat dalam Ayustaningwarno, F. 2014. Teknologi Pangan, Teori Praktis dan Aplikasi. Graha ilmu. Yogyakarta; 2011.

20. Kusumowati ITD, Siswandono, Rudyanto M. Sintesis n-3-chlorobenzoylamoxicillin dan uji aktivitas Antibakterinya terhadap Pseudomonas aeruginosa ATCC 27853. Farmasains. 2011;1(2).

21. Ramos F, et.al. Amoxicillin. http://docplayer. net/49371362-First-draft-prepared-byfernando-ramos-coimbra-portugal-joe-boisonsaskatoon-canada-and-lynn-g-friedlanderrockville-md-usa.html. Diakses tanggal 23 Juli 2018.

22. Kumar. Organic Chemistry Spectroscopy of Organic Compounds. https://www.coursehero. com/file/30238438/publication-11-8282250pdf/. Diakses tanggal 23 Juli 2018

23. Iswari R, Asmono N, Santoso US, Lina S. Pola kepekaan kuman Salmonella terhadap obat kloramfenikol, ampisilin dan kotrimoksazol selama kurun waktu 1979-24. Majalah Kedokteran Indonesia. 1983;36:13-9. 